Kuznets curve in municipal solid waste production: An empirical analysis based on municipal-level panel data from the Lombardy region (Italy)

\title{
Ercolano, Salvatore
}

2018-10

Ercolano , S , Gaeta , G L , Ghinoi , S \& Silvestri , F 2018, ' Kuznets curve in municipal solid waste production: An empirical analysis based on municipal-level panel data from the pÿLombardy region (Italy) ' , Ecological Indicators , vol. 93 , pp. 397403 . https://doi.org/10.1016/j.ecolind.2018.05.0؛

http://hdl.handle.net/10138/307900

https://doi.org/10.1016/j.ecolind.2018.05.021

draft

Downloaded from Helda, University of Helsinki institutional repository.

This is an electronic reprint of the original article.

This reprint may differ from the original in pagination and typographic detail.

Please cite the original version. 


\section{Kuznets curve in municipal solid waste production: An empirical analysis based on municipal-level panel data from the Lombardy region (Italy)}

\section{Salvatore Ercolano ${ }^{\text {a }}$ (please, add also the affiliation c for this author)}

ercolano@issm.cnr.it

\section{Giuseppe Lucio Lucio(The author first name is 'Giuseppe Lucio', not 'Giuseppe Lucio Lucio') Gaeta ${ }^{\mathrm{b}, \mathrm{c}, \text { * }}$}

glgaeta@unior.it

\section{Stefano Ghinoli $^{d}$ (Please, change the affiliation for this author as follow: Department of Economics and Management, University of Helsinki, Latokartanonkaari 5, P.O. Box 27 00014, Helsinki, Finland)} stefano.ghinoi2@unibo.it(Please, change this email with the following: stefano.ghinoi@helsinki.fi)

\section{Francesco Silvestri ${ }^{\mathrm{e}}$ f}

francesco.silvestri@unimore.it

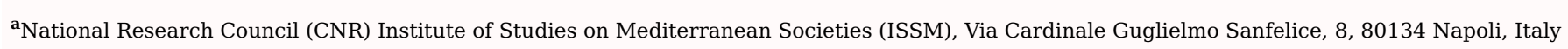

$\mathbf{b}^{\mathbf{b}}$ Department of Human and Social Sciences, University of Naples L'Orientale, Largo San Giovanni Maggiore 30, 80134 Napoli, Italy

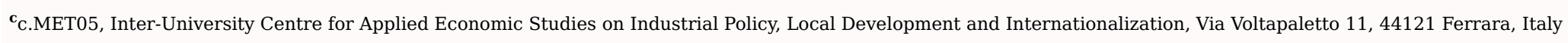

d Department of Agricultural Sciences, University of Bologna, Viale Fanin, 44, 40127 Bologna, Italy

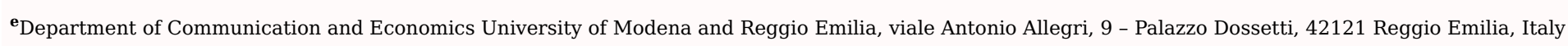

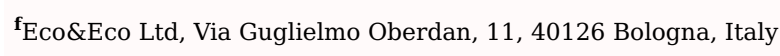

${ }^{*}$ Corresponding author at: Department of Human and Social Sciences, University of Naples L'Orientale, Largo San Giovanni Maggiore 30, 80134 Napoli, Italy.

\section{Abstract}

By using a novel database that observes 1,497 municipalities from the Lombardy region in Italy between 2005 and 2011, this paper provides an empirical test of the Waste Kuznets Curve (WKC) hypothesis.

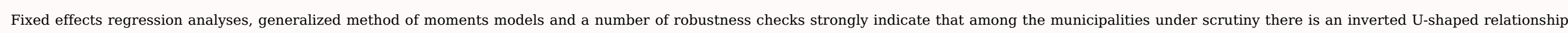

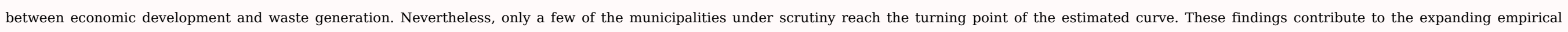
literature that tests WKC by using municipal data, considered the most appropriate for this kind of analysis.

Keywords: Waste generation; Kuznets; Panel data

\section{Introduction}

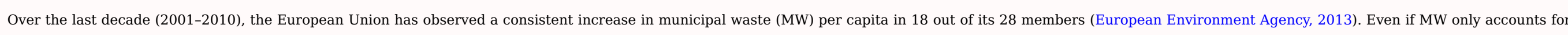

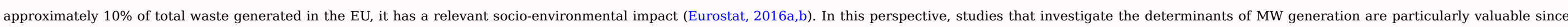
they might inform policies aimed at incentivizing MW reduction, that are very important in the waste management strategy (Beigl et al., 2008).

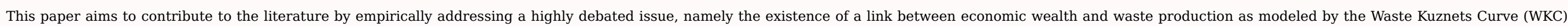




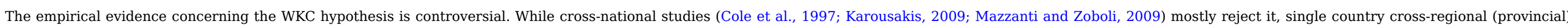

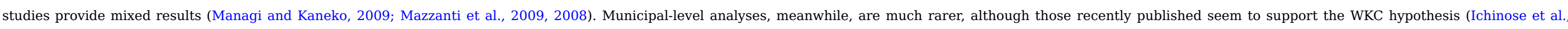
2015).

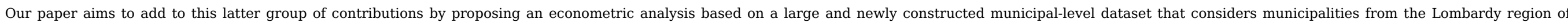
Northern Italy ( $\mathrm{n}=1497)$, which were longitudinally observed between 2005 and 2011.

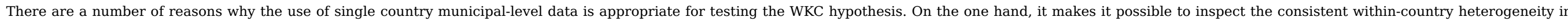

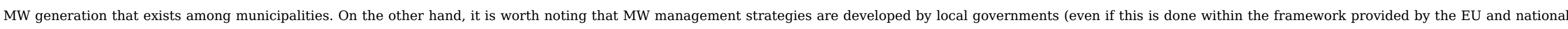
directives; Reggiani and Silvestri, 2017) and this makes the inspection of municipal-level determinants of MW particularly valuable.

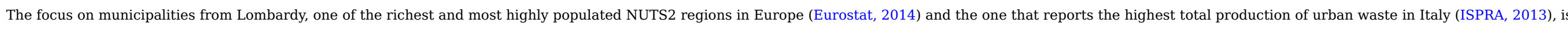
appropriate for our empirical investigation since this region has been suggested to be an appealing case study for inspecting waste production and waste management (Gaeta et al., 2017)

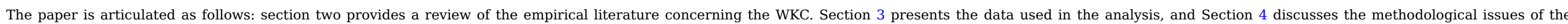
analysis. The results and their discussion are reported in Section 4. Finally, Section 5 draws the conclusions arising from this study.

\section{The environmental Kuznets curve and the waste Kuznets curve hypotheses}

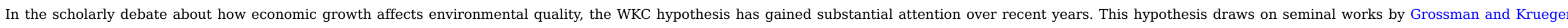
(1991), Holtz-Eakin and Selden (1992), and the World Bank (1992) on the EKC, and suggests an inverted-U shaped relation between deterioration of environmental measures and economic development.

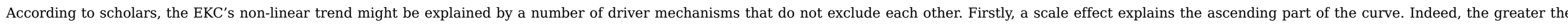

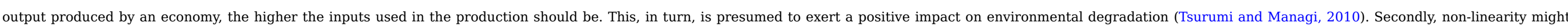

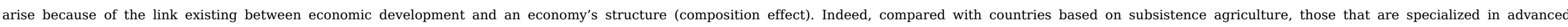

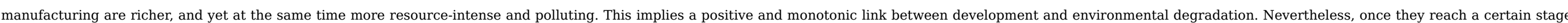

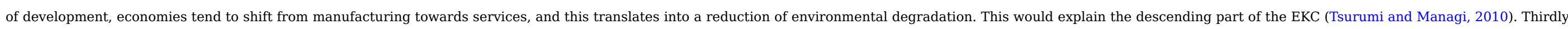

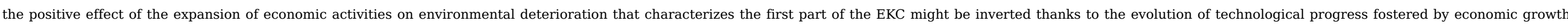

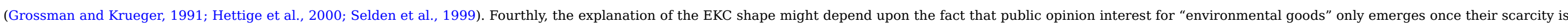
perceived (Unruh and Moomaw, 1998; Torras and Boyce, 1998).

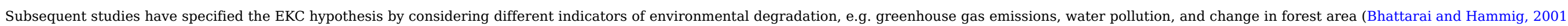

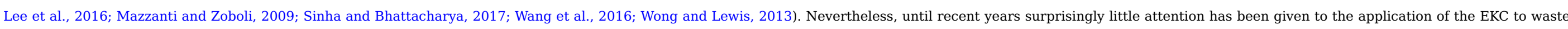
generation, i.e. to the WKC hypothesis, even if the number of contributions specifically focused on this topic is increasing (Abrate and Ferraris, 2010; Mazzanti et al., 2009).

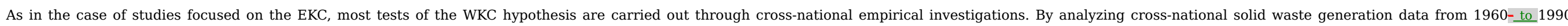

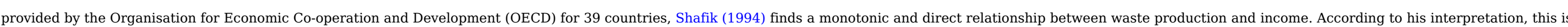

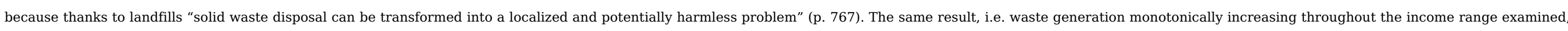

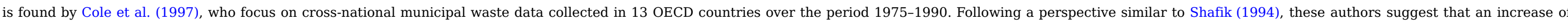

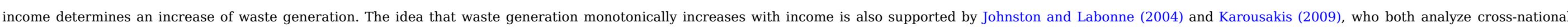

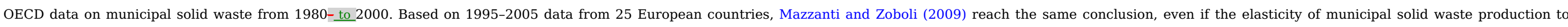

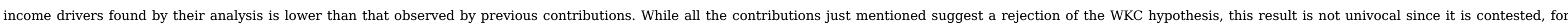




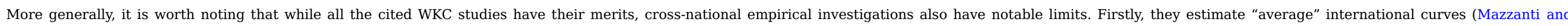

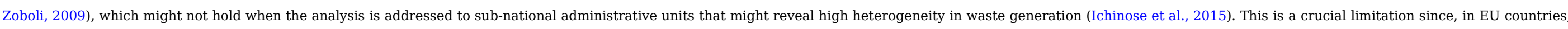

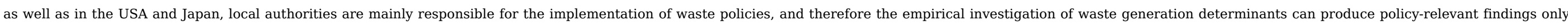

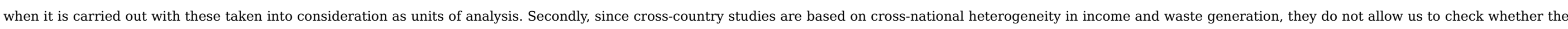
Kuznets curve hypothesis holds for all the countries under scrutiny (Mazzanti et al., 2009; Lim, 1997).

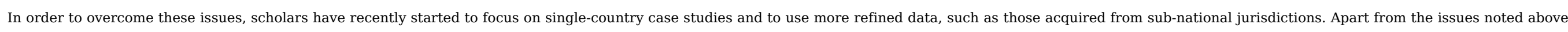

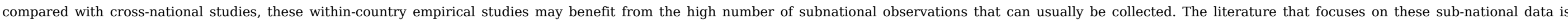
expanding, but still not extensive (Mazzanti et al., 2009).

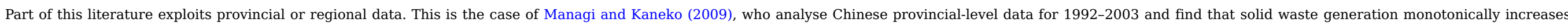

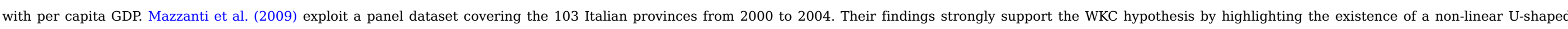

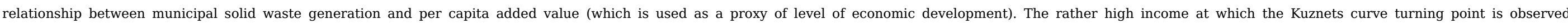
unfortunately suggests that only a few provinces reach the level of wealth where waste generation would be expected to lower.

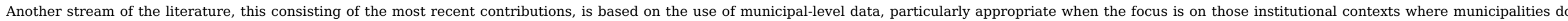

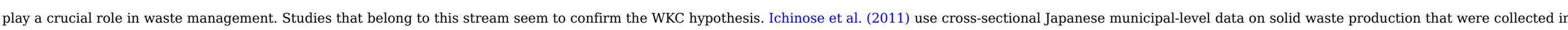

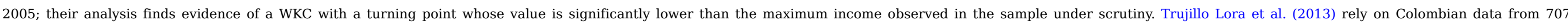

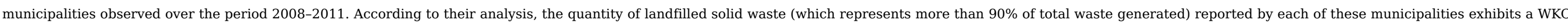

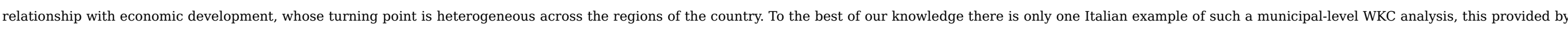

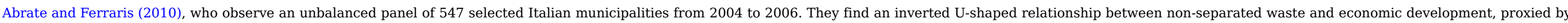

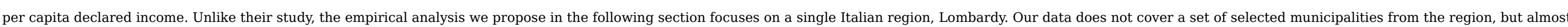
all the existing ones, and this allows us to build a comprehensive and large $(n=1447)$ dataset to be employed in our econometric investigations.

\section{Data}

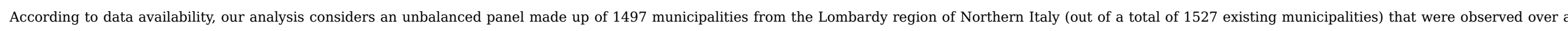

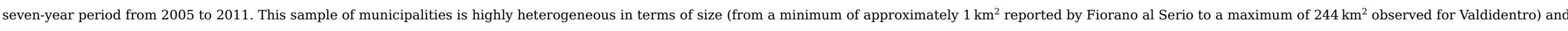
population (from a minimum of 30 reported by Pedesina in 2011 to a maximum of 1,250,000 inhabitants reported by Milan in 2005).

Table 1 presents the variables considered in the empirical study and shows for each of them the corresponding label, definition and data source

Table 1 Labels, description and data sources for variables used in the empirical analysis.

\begin{tabular}{|c|c|c|}
\hline Label & Description & Source \\
\hline MWG & Per capita waste produced per day (kg) & ARPA Lombardy (Regional Enrivornmental Protection Agency)A \\
\hline ECONOMIC_DEV & $\begin{array}{l}\text { Average tax return per inhabitant (total tax return in } € / \text { number of inhabitants) expressed in real terms (base } \\
\text { year }=2005 \text { ) }\end{array}$ & $\begin{array}{l}\text { Own elaboration based on data from the Italian Revenue Agency (Agenzia delle } \\
\text { Entrate) }\end{array}$ \\
\hline DENSITY & Density of inhabitants (number of inhabitants per squared km) & ISTAT (Italian National Institute of Statistics) ${ }^{c}$ \\
\hline OLDSHARE & Share of people more than 65 years old (\%) & ISTAT (National Institute of Statistics) ${ }^{\mathrm{C}}$ \\
\hline ACCOMODATION & Sleeeping accomodation (per capita; number of sleeping accommodation facilities/total population) & Own elaboration on data from ISTAT (Italian National Institute of Statistics) $\mathrm{C}$ \\
\hline
\end{tabular}




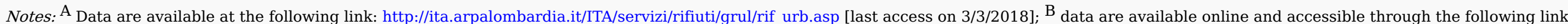

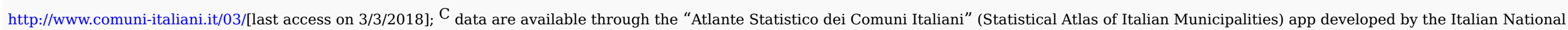
Institute of Statistics and downloadable at the following link: https://www.istat.it/it/archivio/113712.

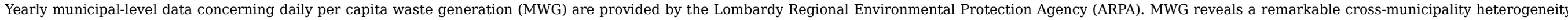

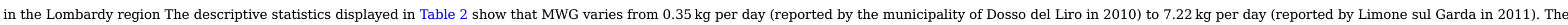

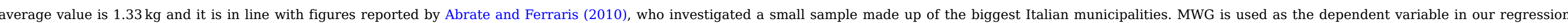
analyses where a wide set of regressors is considered.

Table 2 Descriptive statistics of variables used in the analysis.

\begin{tabular}{|c|c|c|c|c|c|c|}
\hline Variable & & Mean & Std. Dev. & Min & $\operatorname{Max}$ & Observations \\
\hline \multirow[t]{3}{*}{ MWG } & overall & 1.331 & 0.398 & 0.352 & 7.223 & $\mathrm{~N}=10346$ \\
\hline & between & & 0.382 & 0.459 & 6.711 & $\mathrm{n}=1497$ \\
\hline & within & & 0.107 & 0.495 & 3.065 & T-bar $=6.91116$ \\
\hline \multirow[t]{3}{*}{ ECONOMIC_DEV } & overall & 12406.470 & 2573.561 & 1566.194 & 44588.430 & $N=10346$ \\
\hline & between & & 2447.824 & 1803.834 & 29643.670 & $\mathrm{n}=1497$ \\
\hline & within & & 765.527 & 3164.296 & 31107.270 & T-bar $=6.91116$ \\
\hline \multirow[t]{3}{*}{ DENSITY } & overall & 549.979 & 770.979 & 2.524 & 7806.509 & $\mathrm{~N}=10346$ \\
\hline & between & & 767.518 & 2.885 & 7637.363 & $\mathrm{n}=1497$ \\
\hline & within & & 22.187 & 246.639 & 801.359 & T-bar $=6.91116$ \\
\hline \multirow[t]{3}{*}{ OLDSHARE } & overall & 0.197 & 0.049 & 0.044 & 0.511 & $N=10346$ \\
\hline & between & & 0.049 & 0.049 & 0.500 & $\mathrm{n}=1497$ \\
\hline & within & & 0.008 & 0.133 & 0.250 & T-bar $=6.91116$ \\
\hline \multirow[t]{3}{*}{ ACCOMODATION } & overall & 0.031 & 0.163 & 0.000 & 5.104 & $\mathrm{~N}=10346$ \\
\hline & between & & 0.161 & 0.000 & 4.821 & $\mathrm{n}=1497$ \\
\hline & within & & 0.018 & -0.408 & 0.405 & T-bar $=6.91116$ \\
\hline \multirow[t]{3}{*}{ FOREIGN } & overall & 0.067 & 0.041 & 0.000 & 0.291 & $N=10346$ \\
\hline & between & & 0.037 & 0.000 & 0.235 & $\mathrm{n}=1497$ \\
\hline & within & & 0.016 & -0.025 & 0.195 & T-bar $=6.91116$ \\
\hline
\end{tabular}

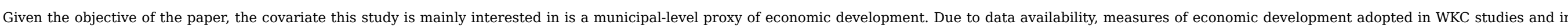

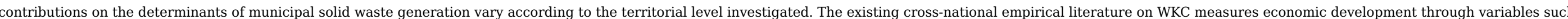

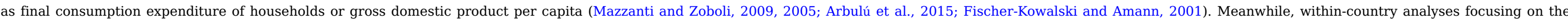
regional or provincial level use gross regional product (Managi and Kaneko, 2009) or per capita value added (VA) (Mazzanti et al., 2008, 2009, 2011, 2012; Mazzanti and Zoboli, 2009; D’Amato et al., 2015). 


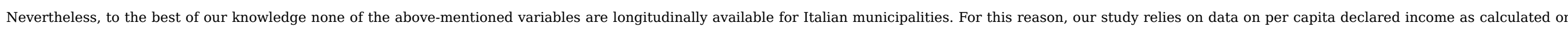

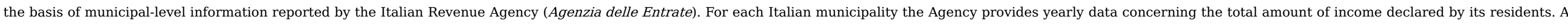

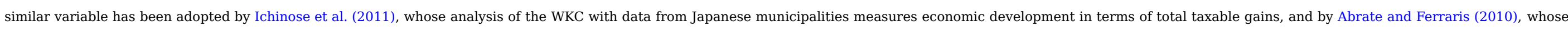
investigation of Italian data from a sample of municipalities relies on fiscal data from the Italian Ministry of Internal Affairs.

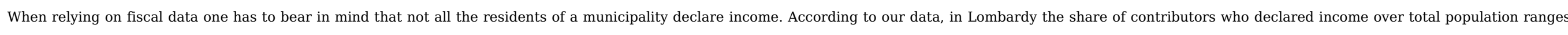

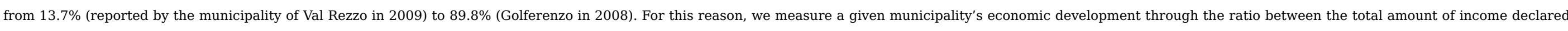
by its residents and the total number of residents. The resulting per capita municipality income is expressed in real terms (euro, base year =2005), and is labeled as ECONOMIC_DEV.

Consistently with the existing literature on WKC, the empirical investigation also considers four other time-variant covariates.

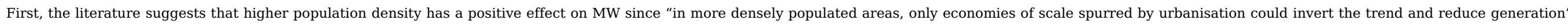
(Mazzanti and Zoboli, 2009, p. 215). Therefore, municipality population density (labeled DENSITY) is included among regressors.

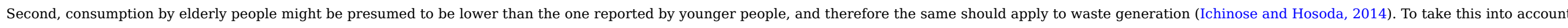
a variable (OLDSHARE) measuring the share of people aged $>65$ in each municipality is added to the set of covariates considered.

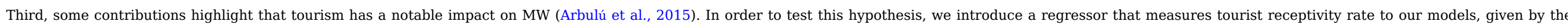
number of facilities for tourist accommodation existing in each municipality divided by the number of residents. This variable is labeled ACCOMMODATION.

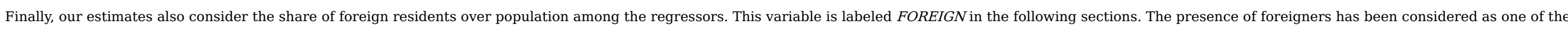

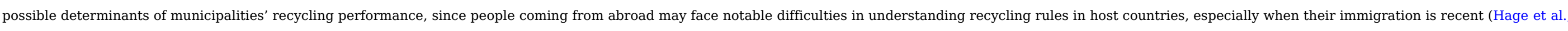

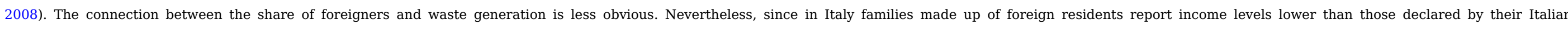

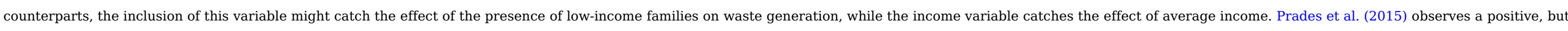
not statistically significant, influence of foreigners on waste generation.

Descriptive statistics for all the variables presented in this section are displayed in Table 2.

\section{Methodology}

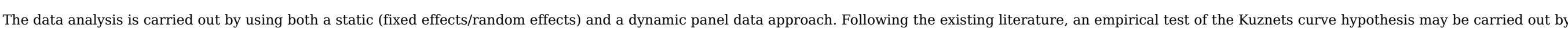
estimating the following equation:

$M W G_{i t}=\beta_{1} E_{C O N O M I C_{D E V i t}}+\beta_{2} E_{C O N O M I C}^{2} C_{D V i t}+\beta_{k} X_{i t}+\zeta_{t}+u_{i}+\varepsilon_{i t}$

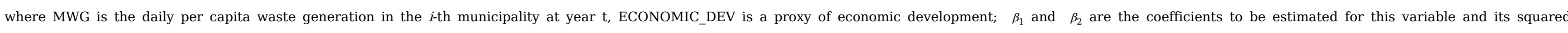

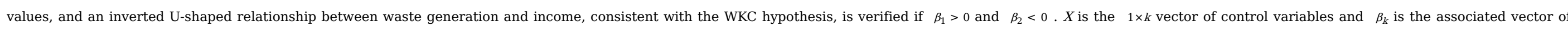
coefficients while $\zeta_{t}$ represents time fixed effects. Finally, $u_{i}$ is the municipal (individual)-level effect and $\varepsilon_{i t}$ is the disturbance term.

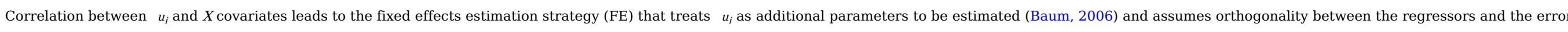

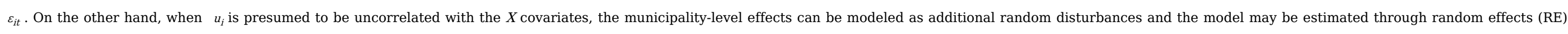

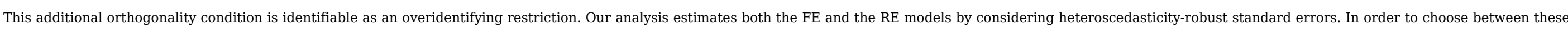
two estimation strategies, a Sargan/Hansen test is run with the aim of testing the extra restrictions imposed by RE.

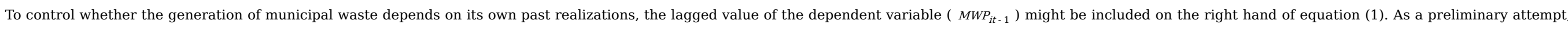

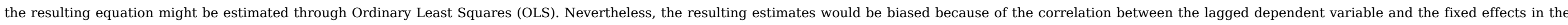




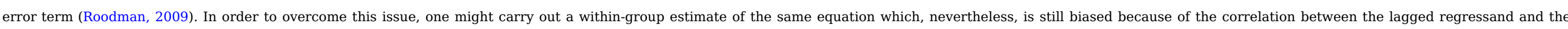
error term (Bond, 2002; Roodman, 2009).

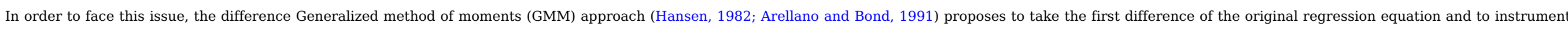

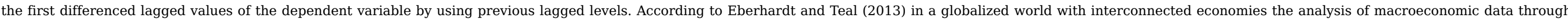

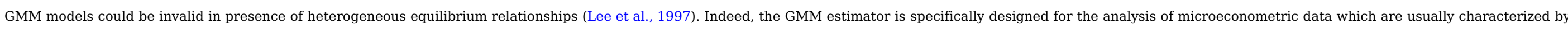

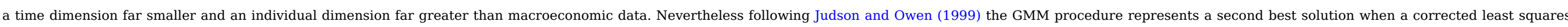

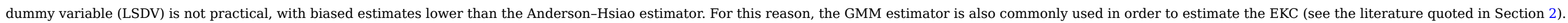

\section{Results}

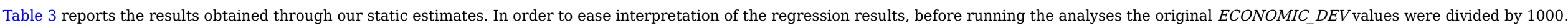

\begin{tabular}{|c|c|c|c|}
\hline & (1) & (2) & (3) \\
\hline \multirow[t]{2}{*}{ ECONOMIC_DEV $(\times 1000)$} & $0.0424^{* * *}$ & $0.0477^{* * * *}$ & $0.0489^{* * *}$ \\
\hline & $(0.0094)$ & $(0.0121)$ & $(0.0105)$ \\
\hline \multirow[t]{2}{*}{ ECONOMIC_DEV^2 $(\times 1000)$} & $-0.0009^{* * * *}$ & $-0.0010^{* * *}$ & $-0.0010^{* * *}$ \\
\hline & $(0.0003)$ & $(0.0003)$ & $(0.0003)$ \\
\hline \multirow[t]{2}{*}{ DENSITY } & & & $-0.0001^{* * *}$ \\
\hline & & & $(0.0000)$ \\
\hline \multirow[t]{2}{*}{ OLDSHARE } & & & $1.0718^{* * *}$ \\
\hline & & & $(0.1680)$ \\
\hline \multirow[t]{2}{*}{ ACCOMODATION } & & & $1.0530^{* * *}$ \\
\hline & & & $(0.1055)$ \\
\hline \multirow[t]{2}{*}{ FOREIGN } & & & $-0.5691^{* * *}$ \\
\hline & & & $(0.1790)$ \\
\hline Observations & 10,346 & 10,346 & 10,346 \\
\hline Number of ID & 1,497 & 1,497 & 1,497 \\
\hline Year dummy & No & Yes & Yes \\
\hline Fixed/Random & Random & Fixed & Fixed \\
\hline Sargan-Hansen statistic & 4.858 & 6842.367 & 264.143 \\
\hline $\mathrm{p}$ & 0.088 & 0.000 & 0.000 \\
\hline Turning point & $€ 23,555$ & $€ 23,850$ & $€ 24,450$ \\
\hline
\end{tabular}

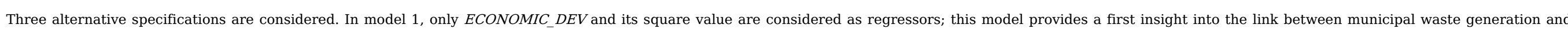

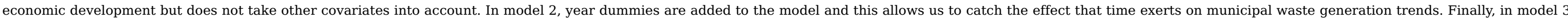




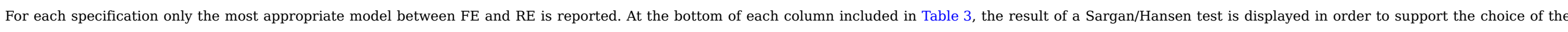

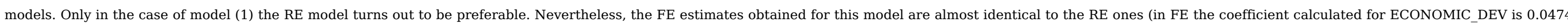
while the one calculated for ECONOMIC_DEV^2 is -0.0009).

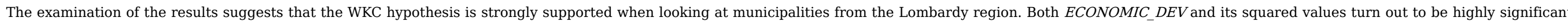

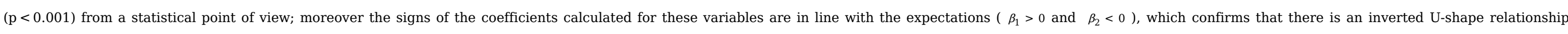
between MW and economic development.

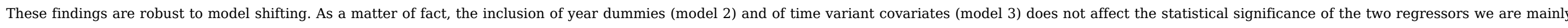
interested in, and the same is true for the signs of the estimated $\beta_{1}$ and $\beta_{2}$.coefficients. Even the size of the coefficients does not dramatically change from one model to another.

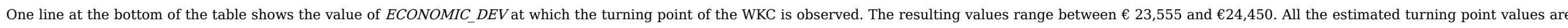

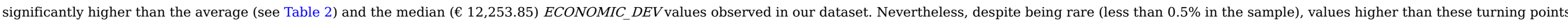

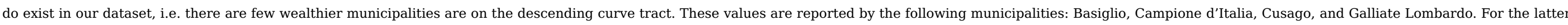
two, values higher than $€ 25,000$ are observed only for a subset of the years considered.

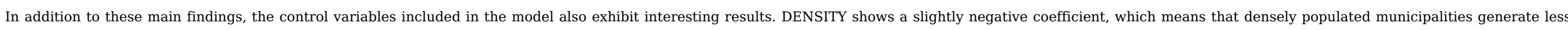

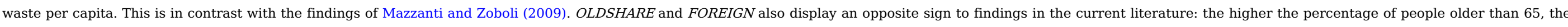

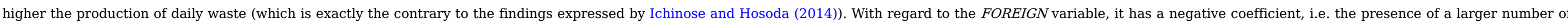

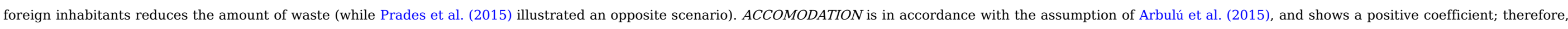
tourism is confirmed as having a positive impact on waste creation.

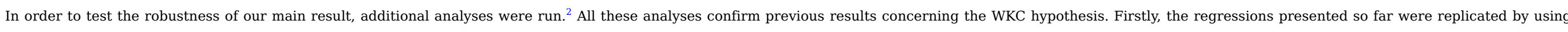

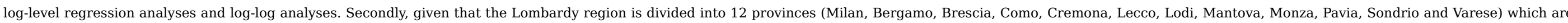

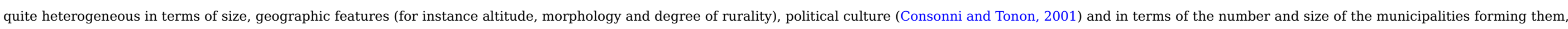

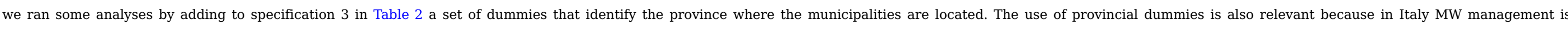

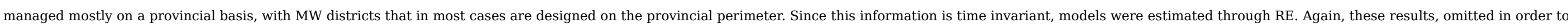
save space, strongly confirm our main findings concerning the EKC.

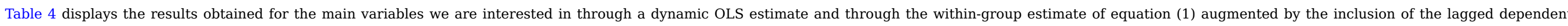

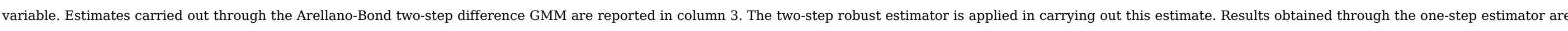

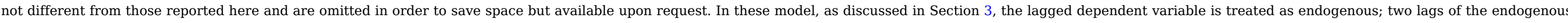

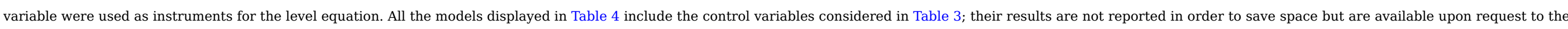
authors.

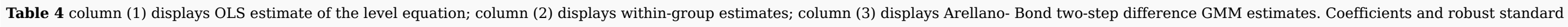

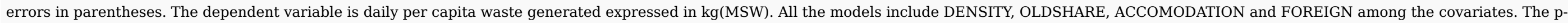
value of the serial correlation tests and the $\mathrm{p}$-value of the Hansen test of overidentification are reported in square brackets. Notes: ${ }^{* * *} \mathrm{p}<0.01{ }^{* *} \mathrm{p}<0.05$. 
(a)

$-0.0011^{*}$

$-0.0007^{\text {**e }}$

$-0.0006^{\text {*at }}$

\section{Year dummy}

$(0.0000)$

(0.0000)

(0.0002)

Arellano-Bond test for AR(1) in first differences $\mathrm{z}$ and $\mathrm{p}$ [in parentheses]

Arellano-Bond test for AR(1) in first differences $\mathrm{z}$ and $\mathrm{p}$ [in parentheses]

Yes

Yes

Hansen test of overid. restrictions: chi2 and p [in parentheses]

Turning point

Yes

Yes

-5.28 [0.000]

$0.71[0.478]$

7.96 [0.093]

$€ 27,750$

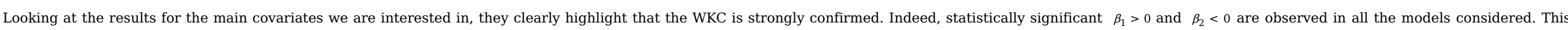
provides additional evidence that there is a non-linear inverted U-shaped relationship between waste generation and economic development. Coefficients estimated through the models (3).

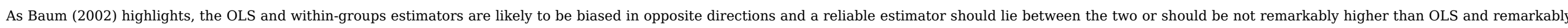

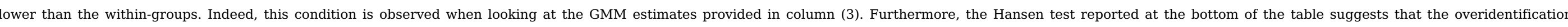

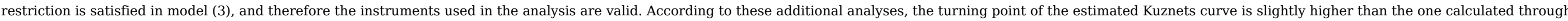
the static panel investigation, since it is observed at €28,071. Fig. 1 provides a graphical representation of the estimated Kuznets curve.

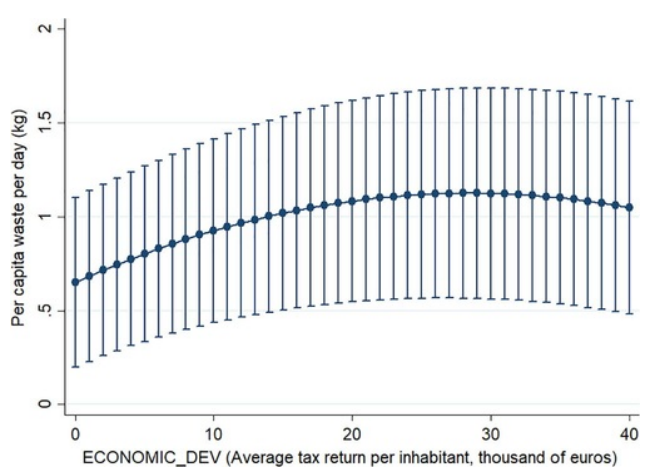

Fig. 1 Non-linear relation between economic development and waste production as resulting from the estimates provided by model (3) in Table 4 . Vertical lines represent $95 \%$ confidence interval.

\section{Conclusion}

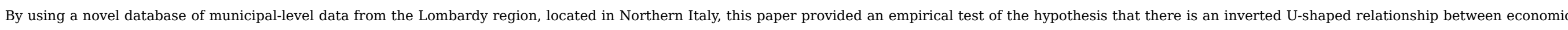

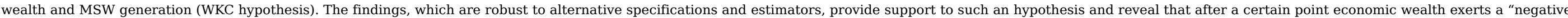
scale effect" on waste generation which might be due to a rising care for the non-materialistic goal of waste generation reduction.

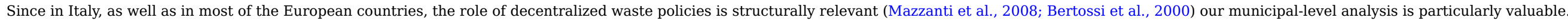

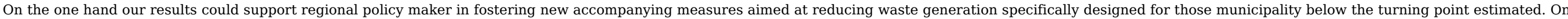




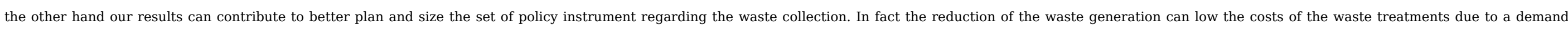
effect.

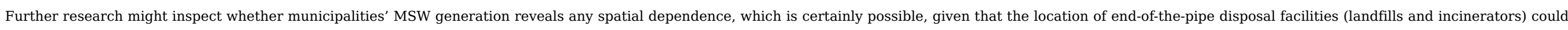
encourage some municipalities to reduce MW production and increase MW recycling.

\section{Uncited reference}

\section{Apergis and Ozturk (2015).}

\section{References}

Abrate, G., Ferraris, M., 2010. The environmental Kuznets curve in the municipal solid waste sector. HERMES Working Paper, 1.

Arbulú I., Lozano J. and Rey-Maquieira J., Tourism and solid waste generation in Europe: a panel data assessment of the Environmental Kuznets Curve, Waste Manage. (Oxford) 46, 2015, 628-636.

Arellano M. and Bond S., Some tests of specification for panel data: Monte Carlo evidence and an application to employment equations, Rev. Econ. Stud. 58 (2), $1991,277-297$.

Apergis N. and Ozturk I., Testing environmental Kuznets curve hypothesis in Asian countries, Ecol. Ind. 52, 2015, 16-22.

Baum C.F., An Introduction to Modern Econometrics using Stata, 2006, Stata press.

Beigl P., Lebersorger S. and Salhofer S., Modelling municipal solid waste generation: a review, Waste Manage. (Oxford) 28, 2008, $200-214$.

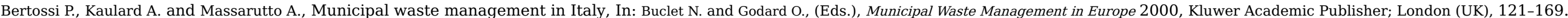

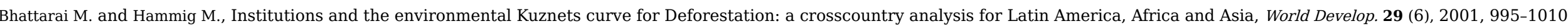
Bond S.R., Dynamic panel data models: a guide to micro data methods and practice, Portuguese Econ. J. 1 (2), 2002, 141-162.

Cole M., Rayner A. and Bates J., The environmental Kuznets curve: an empirical analysis, Environ. Dev. Econ. 2, 1997, 401-416.

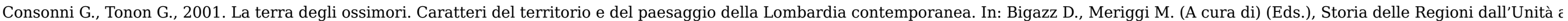
oggi. La Lombardia, 53-187.

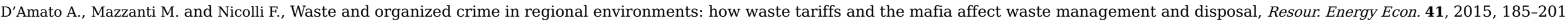

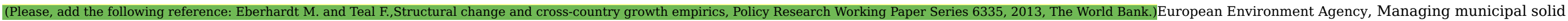

waste - a review of achievements in 32 European countries, 2013, Publications Office of the European Union; Luxembourg.

Eurostat, 2014. GDP at regional level, available online at http://ec.europa.eu/eurostat/statistics-explained/index.php/GDP_at_regional_level [last access on 13/8/2017].

Eurostat, 2016. Waste database municipal waste.

Eurostat, 2016. Waste database generation of waste.

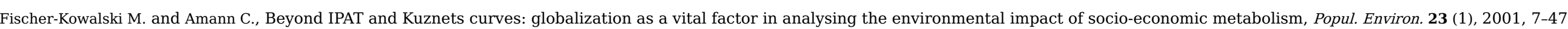

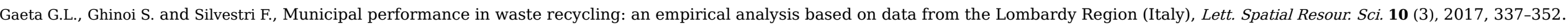

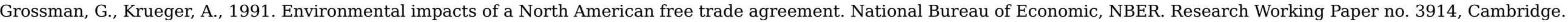

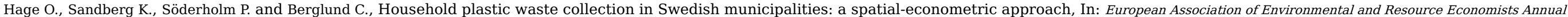


Conference. 25/06/2008-28/06/2008 2008.

Hansen L.P., Large sample properties of generalized method of moments estimators, J. Econometric Soc. 1982, 1029-1054.

Hettige H., Mani M. and Wheeler D., Industrial pollution in economic development: the environmental Kuznets curve revisited, J. Dev. Econ. 62, $2000,445-476$.

Holtz-Eakin D. and Selden T.M., Stoking the fires? CO2 emissions and economic growth, 1992, National Bureau of Economic Research; Cambridge, Massachusetts, NBER working papers 4248.

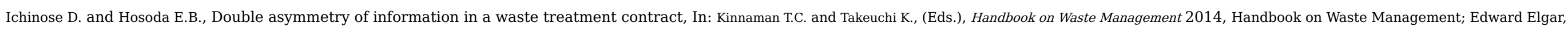

Cheltenham, 394-415.

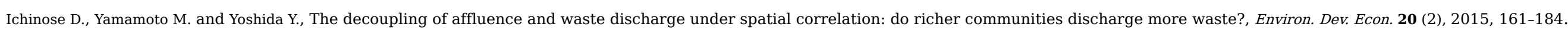

Ichinose D., Yamamoto M. and Yoshida Y., Reexamining the waste-income relationship, 2011, National Graduate Institute for Policy Studies; Tokyo: Japan, GRIPS Discussion Paper No. 10-31.

ISPRA, 2013. Rapporto Rifiuti Urbani. Edizione 2013. ISPRA, Rapporto n.176/2013.

Johnstone N. and Labonne J., Generation of household solid waste in OECD countries: an empirical analysis using macroeconomic data, Land Econ. 80 (4), 2004, 529-538.

Judson R.A. and Owen A.L., Estimating dynamic panel data models: a guide for macroeconomists, Econ. Lett. 65 (1), 1999, 9-15.

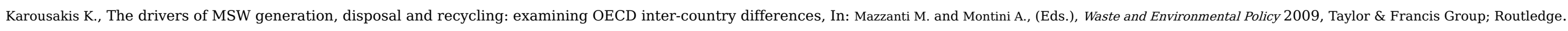
Lee S., Kim J. and Chong W.K.O., The causes of the municipal solid waste and the greenhouse gas emissions from the waste sector in the United States, Waste Manage. (Oxford) 56, 2016, 593-599.

Lee K., Pesaran M.H. and Smith R., Growth and convergence in a multi-country empirical stochastic Solow model, J. Appl. Econometrics 1997, 357-392.

Lim J., The effects of economic growth on environmental quality: some empirical investigation for the case of South Korea, Seoul J. Econ. 10, 1997, $272-293$.

Managi S. and Kaneko S., Environmental performance and returns to pollution abatement in China, Ecol. Econ. 68 (6), $2009,1643-1651$.

Mazzanti M. and Zoboli R., Municipal waste Kuznets curves: evidence on socio-economic drivers and policy effectiveness from the EU, Environ. Resour. Econ. 44 (2), 2009, 203-230.

Mazzanti M. and Zoboli R., Delinking and environmental Kuznets curves for waste indicators in Europe, Environ. Sci. 2 (4), 2005, 409-425.

Mazzanti M., Montini A. and Nicolli F., Embedding landfill diversion in economic, geographical and policy settings, Appl. Econ. 43 (24), 2011 , 3299-3311.

Mazzanti M., Montini A. and Nicolli F., Waste dynamics in economic and policy transitions: decoupling, convergence and spatial effects, J. Environ. Plan. Manage. 55 (5), 2012, 563-581.

Mazzanti M., Montini A. and Zoboli R., Municipal waste generation and socioeconomic drivers: evidence from comparing Northern and Southern Italy, J. Environ. Develop. 17 (1), 2008, 51-69.

Mazzanti M., Montini A. and Zoboli R., Municipal waste generation and the EKC hypothesis new evidence exploiting province-based panel data, Appl. Econ. Lett. 16 (7), 2009, 719-725.

Prades M., Gallardo A. and Ibàñez M.V., Factors determining waste generation in Spanish towns and cities, Environ. Monit. Assess. 187 (1), 2015.

Raymond L., Economic growth as environmental policy? Reconsidering the environmental Kuznets Curve, J. Public Pol. 24 (3), $2004,327-348$.

Reggiani C. and Silvestri F., Municipal solid waste, market competition and the EU policy, Environ. Resour. Econ. 1-18, 2017, https://doi.org/10.1007/s10640-017-0165-0, first online.

Roodman D., How to do xtabond2: an introduction to difference and system GMM in Stata, Stata J. 9 (1), 2009, 86-136.

Selden T.M., Forrest A.S. and Lockhart J.E., Analyzing the reductions in U.S. Air Pollution Emissions: 1970 to 1990, Land Econ. 75 (1), $1999,1-21$.

Shafik N., Economic development and environmental quality: an econometric analysis, Oxford Econ. Papers 46, 1994, 757-773. 
Sinha A. and Bhattacharya J., Estimation of environmental Kuznets curve for SO2 emission: a case of Indian cities, Ecol. Ind. 72, 2017, 881-894.

Stern D., The rise and fall of the Environmental Kuznets curve, World Dev. 32 (8), 2004, 1419-1438.

Torras M. and Boyce J.K., Income, inequality and pollution: a reassessment of the environmental Kuznets curve, Ecol. Econ. 25, 1998, 147-160.

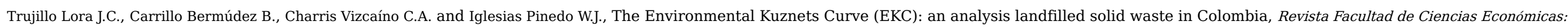

Investigación y Reflexión 21 (2), 2013, 7-16.

Tsurumi T. and Managi S., Decomposition of the environmental Kuznets curve: scale, technique, and composition effects, Environ. Econ. Policy Stud. 11 (1-4), $2010,19-36$.

Unruh G.C. and Moomaw W.R., An alternative analysis of apparent EKC-type transitions, Ecol. Econ. 25, 1998, 221-229.

Wang Z., Bao Y., Wen Z. and Tan Q., Analysis of relationship between Beijing's environment and development based on Environmental Kuznets Curve, Ecol. Ind. 67, 2016 , 474-483.

Wong Y.L. and Lewis L., The disappearing Environmental Kuznets Curve: a study of water quality in the Lower Mekong Basin (LMB), J. Environ. Manage. 131, 2013, 415-425.

World Bank, World Development Report 1992: Development and the Environment, 1992, Oxford University Press; New York.

\section{Footnotes}

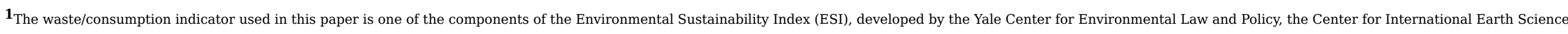
Information Network at Columbia University, and the World Economic Forum in order to rank countries according to their environmental sustainability.

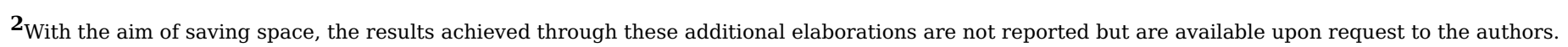

\section{Highlights}

- Municipal-level waste generation data from the Lombardy region Italy are inspected.

- The waste Kuznets curve (WKC) hypothesis is empirically tested.

- An inverted U-shaped link between waste and economic development is found.

- The estimated turning point of the WKC is approximately between $€ 23,500$ and $€ 28,000$.

\section{Queries and Answers}

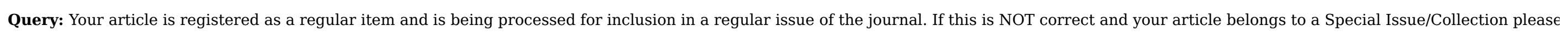
contact p.sivakumar@elsevier.com immediately prior to returning your corrections.

Answer: Yes

Query: The author names have been tagged as given names and surnames (surnames are highlighted in teal color). Please confirm if they have been identified correctly. Answer: Yes

Query: Please check the address for the corresponding author that has been added here, and correct if necessary.

Answer: The address is correct

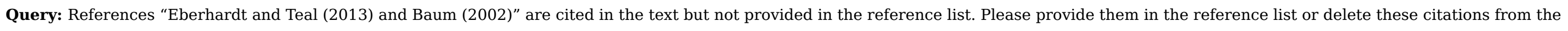


text.

Answer: The reference has been added in the reference list

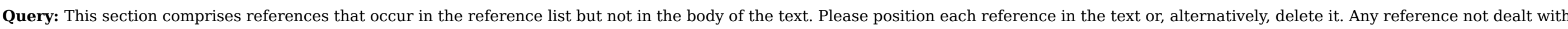
will be retained in this section.

Answer: The uncited reference can be deleted

Query: Please check the layout of Table 2, and correct if necessary.

Answer: the table is ok. 